\title{
ENDEMIC HEPATITIS B AND C VIRUS INFECTION IN A BRAZILIAN EASTERN AMAZON REGION
}

\author{
Marcelo EI KHOURI', Quirino CORDEIRO'1, Diogo Arantes Behling Pereira da LUZ1', \\ Leandro Savoy DUARTE${ }^{1}$, Mônica Elinor Alves GAMA² and Carlos Eduardo Pereira CORBETT ${ }^{1}$
}

\begin{abstract}
Context - Hepatitis B and hepatitis C infection has been an important cause of morbidity and mortality around the world. However there are few investigations regarding the prevalence and possible risk factors for these diseases in Brazil, particularly in Amazon region, where there are some endemic focus. Objective - To determine the prevalence of hepatitis B and hepatitis $\mathrm{C}$ in the city of Buriticupu, MA, located in the Brazilian Eastern Amazon region, and try to explore the risk factors for these infections in that area. Methods - Two hundred forty three subjects (46.5\% male and 53.5\% female) were investigated. Results - The prevalence of past or current infection of hepatitis B and C virus was, respectively, 40.74\% and 5.76\%. Positivity for HBsAg was found in $2.88 \%$ of the subjects. The prevalence of current infection or chronic virus carriers found was $2.88 \%(\mathrm{HBs} \mathrm{Ag})$. There was a statistically significant relationship between the sera-prevalence of anti-HBc and the distance of the residence from the city center which may reflect an indirect association between the infection and precarious conditions of existence. Individuals with age equal or greater than 60 years were also more likely to be anti-HBc positive which could only reflect that older people have a longer history of exposure to hepatitis B infection. The prevalence of hepatitis $\mathrm{C}$ is higher than the worldwide estimate. Conclusion - Buriticupu may be considered endemic for hepatitis B and C. Hepatitis B infection could be related to precarious living conditions and old age. Hepatitis C was not associated with the variables investigated in the present investigation.
\end{abstract}

HEADINGS - Hepatitis B, epidemiology. Hepatitis C, epidemiology. Seroepidemiologic studies. Hepatitis B core antigens. Hepatitis B surface antigens.

\section{INTRODUCTION}

There are an estimated 350 million chronic carriers of hepatitis B virus (HBV) worldwide ${ }^{(24)}$, with 300,000 new cases reported in the United States annually ${ }^{(11)}$. Regional prevalence varies significantly on a global scale. Areas such as Africa, Southeast Asia and China, with infection rates of $15 \%-20 \%$, have been considered to have the highest prevalence of HBV infection (more than 8\%) in the world. Eastern Europe exhibits an intermediate rate of infection (2\%-7\%), and Western Europe, North America, New Zealand, Australia and Japan have the lowest rates of infection (less than $2 \%)^{(1,7,26,31)}$. The prevalence of $\mathrm{HBV}$ in Brazil is estimated in approximately $7.9 \% \%^{(3)}$. Within Brazil, infection rates range from $21 \%$ in Manaus and $1.2 \%$ in Fortaleza ${ }^{(12)}$. HBV is currently considered endemic in some areas of the Amazon region $^{(26)}$, in special in the Western Amazon, in an area correspondent to the States of Acre, Amazonas, Rondônia and Roraima ${ }^{(6)}$.

There were 7,308 confirmed cases of HBV in Brazil in 2003, 156 of which occurred in the state of
Maranhão ${ }^{(4)}$. In the State of Maranhão, approximately $35.36 \%$ of the population was immunized against hepatitis B during the first year of life in 1999. Thus, the majority of the population may still be susceptible to HBV infection ${ }^{(5)}$.

The main mechanisms involved in the HBV transmission are related to the percutaneous exposition to blood and their derivates, perinatal and sexual exposition ${ }^{(23)}$. In areas where HBV is highly endemic the virus is frequently transmitted during the childhood, from the mothers to the newborn, during the pregnancy or in the delivery process ${ }^{(28)}$, or from children to children, probably due to skin lesions, such as scabies infestations, and impetigo ${ }^{(36)}$. The HBV transmission through insects has been hypothesized and debated for decades. The HBV virus may survive inside the mosquito and bedbug gut, however the virus does not replicate in such condition. Thus the insects could be only a mechanic vector for the infection however this via for HBV transmission remains uncertain ${ }^{(23,38)}$.

Although less prevalent than $\mathrm{HBV}$, hepatitis $\mathrm{C}$ virus (HCV) is a more common cause of chronic hepatitis 
and a major health problem worldwide ${ }^{(2,9,17)}$. There are about 170 million individuals infected with HCV worldwide, approximately $3 \%$ of the global population. The $\mathrm{HCV}$ is responsible for $20 \%-25 \%$ of acute and chronic hepatitis cases in many countries ${ }^{(10,21)}$. Twenty eight thousands new cases of $\mathrm{HCV}$ have been reported per year in the United States, where there are 3.9 million infected subjects $(1.8 \%$ of the general population), 2.7 million of which are chronically infected $^{(35)}$. Brazil does not maintain official records of the prevalence of $\mathrm{HCV}^{(27,29)}$. Among Karitiana Indians living in the State of Rondônia, Southwestern Brazilian Amazon, the prevalence of anti-HCV antibodies were detected in two subjects $(1.7 \%)^{(18)}$. A seroprevalence of $2.4 \%$ associated with intravenous drug use was found in southern Brazilian Amazon ${ }^{(30)}$. HCV prevalence increases exponentially among patients who require hemodyalisis (20\%-30\%) and among users of intra-venous drugs (50\%$90 \%)^{(8,19,22,33,34)}$. Inoculations and blood transfusions are the main routes of transmission, and HCV infection is the main cause of post-transfusion hepatitis, accounting for $80 \%-90 \%$ of all cases ${ }^{(11)}$.

A partnership with the Brazilian Ministry of Health, the Government of Maranhão, and the local public health system, as well as the support of the Federal University of Maranhão (UFMA), made the "Bandeira Científica" (Scientific Flag) Project possible in the city of Buriticupu, in the state of Maranhão, Brazil ${ }^{(15)}$. Buriticupu is located 450 $\mathrm{km}$ from the state capital, São Luis. Its warm and humid climate is typical of the equatorial forests of the Amazon region. The city has a population of approximately 50,000 inhabitants, and $14 \%$ of the district area is used for farming. Buriticupu lacks adequate infrastructure of water treatment, and has a poor educational system. Illiteracy is common among adults over 20 years of age, and the Brazilian census of 2000 showed an illiteracy rate of $63.8 \%$ among residents older than 10 years old.

The Center for Medical Assistance and Research ("Núcleo de Assistência e Pesquisa") associated with the UFMA stands out in the city in local health care. UFMA provides health care in the city through regular clinical assistance for the four most common endemic diseases for the region: malaria, leprosy, leishmaniasis and tuberculosis. When the clinical diagnoses of these diseases are made, treatment is provided and medications supplied by the Brazilian Ministry of Health. Medical students from the University of São Paulo (USP) have organized the "Bandeira Científica" Project. Its purpose is to provide basic health care and educational workshops to impoverished communities, as well as promote regional epidemiological studies. The present study was result of the "Bandeira Científica" Project in Buriticupu.

The purpose of this investigation was to evaluate the seroprevalence of $\mathrm{HBV}$ and $\mathrm{HCV}$ infection in a region of the Eastern Amazon and to try to relate such results to socio-demographic conditions. In regard to $\mathrm{HBV}$, the prevalence was estimated by determining total anti-HBc antibodies ( $\operatorname{IgM}$ and $\operatorname{IgG})$, which reflects both past and recent infections.

\section{METHODS}

Medical students from USP have collected blood samples, during health care activities in 13 rural and urban locations in Buriticupu city. Participants were recruited for medical consultations by local health care providers and invited to participate in this study. The activities have lasted 10 days.

Venous blood samples, 243, were collected, after consent was obtained from participants, who were informed of the nature of the study. The group was selected to include a similar distribution of sex and age classes. Participants were asked to respond to a questionnaire for later statistical analysis. Vacutainer ${ }^{\circledR}$ tubes were used to collect blood samples, which were transported to São Paulo in dry ice at a temperature of $-70^{\circ} \mathrm{C}$. There was no participant who refused to consent for the study.

Laboratory analysis included specific tests for the detection of antibodies for HBV and HCV. These tests were:

1. HBV: ELISA test (Dade Behring) - using a Multiskan EX (Lab System $\left.{ }^{\circledR}\right)$ with screening markers for diagnosis of infection and immunity: tests for total anti-HBc (IgM and $\mathrm{IgG}), \mathrm{HBsAg}$ and anti-HBs ${ }^{(14)}$.

2. HCV: ELISA test (Hemagen) - using a Multiskan EX (Lab System $\left.{ }^{\circledR}\right)$ with confirmation of all positive cases based on the same test in order to obtain higher predictive $\operatorname{power}^{(13,25)}$.

Data was stored in an Excel $2000{ }^{\circledR}$ worksheet comprising information from the questionnaires and the serology results. The statistical analysis was based on frequencies and the Odds-Ratio estimated by univariate and multivariate logistic regression.

In the univariate analysis, the factors associated with presence of anti-HBc positive were analyzed individually. The initial multivariate model also included all variables associated with anti-HBc positive in the univariate analysis, at a level of 0.05 or less. In the final model, only variables that maintained an association at a level of 0.20 or less were retained (we considered here the Wald statistic backward stepwise selection). The statistical analysis was performed using SPSS (Statistical Package for Social Sciences) for Windows, version 14.0.

This study was approved by the Ethics Committee for Analysis of Research Projects (CAPPesq) of "Hospital das Clínicas" of the University of São Paulo Medical School (Protocol 610/02) and it is in accordance to the Declaration of Helsinki.

\section{RESULTS}

The population studied was made up of 243 individuals, $46.5 \%$ male and $53.5 \%$ female. The average age was approximately 35 years, and individuals' ages varied from 1 to 87 years. Seventy nine point seven percent of participants were born in the state of Maranhão; $56.4 \%$ were married or living with a partner; $48.4 \%$ work as laborers; $81.2 \%$ of participants are illiterate or did not complete 1 year of formal education. Average annual 
household income is approximately US\$ 753.11/year, with an average of five individuals per household.

Typical housing has a cement floor $(48.1 \%)$ and wood or mud walls $(51.2 \%) ; 89.3 \%$ of families owned their houses. Most participants burn their solid waste, dispose untreated effluent directly into rivers or onto unused land, and obtain water from wells.

Among personal habits, $67.7 \%$ of participants had previously been admitted to a hospital, $31.4 \%$ currently used tobacco products, $13.6 \%$ consume alcohol, $57.9 \%$ had at least one sexual partner in the last year, and no participant reported intravenous drug use. There was no information regarding hepatitis $\mathrm{B}$ vaccination. The subjects had no history of treatment for hepatitis B and C virus infection.

The medical consultation performed was the main reason for visiting the sampling station for $79.5 \%$ of individuals.

Table 1 shows serological results. The prevalence of $\mathrm{HCV}$ was $5.76 \%$ (anti-HCV) and the prevalence of $\mathrm{HBV}$ was $40.74 \%$ (anti-HBc). Of the 12 participants who were positive for $\mathrm{HCV}$, only 1 was also positive for HBV. Two point eighty eight percent showed signs of current $\mathrm{HBV}$ infection (AgHBs), and $46.09 \%$ tested positive for anti-HBs, indicating immunity against HBV. There were two cases in which anti-HBc was negative and $\mathrm{AgHBs}$ was positive. Seventy one point fifty six percent of immunity in this population was probably due to contact with HBV (anti-HBc and anti-HBs positives), while $28.44 \%$ is due to vaccination without having any previous contact with $\mathrm{HBV}$ (anti-HBc and HBsAg negative with antiHBs positive). The latter group represents $12.76 \%$ of the population studied. Anti-HBc positive had a linear increase with age and anti-HBs positive trended to be stable along the age groups. When these groups were analyzed together, anti-HBs positive with anti-HBc positive had a considerable increase after 20 years-old whereas anti-HBs positive with anti $\mathrm{HBc}$ negative had an opposite pattern. Finally, $\mathrm{HbsAg}$ positive and anti-HCV positive had similar pattern among individuals from 11 to 60 years-old.

TABLE 1. Serological results for hepatitis B and C

\begin{tabular}{lcc}
\hline & $\mathrm{n}$ & Positive (\%) \\
\hline Anti-HCV $^{+}$ & 243 & $14(5.76)$ \\
Anti-HBc $^{+}$ & 243 & $99(40.74)$ \\
$\mathrm{HbsAg}^{+}$ & 243 & $7(2.88)$ \\
Anti-HBs $^{+}$ & 243 & $112(46.09)$ \\
$\mathrm{HBsAg}^{+}$among Anti-HBc & 59 & $5(5.05)$ \\
Anti-HBc $^{+}$and Anti-HBs & 243 & $78(32.10)$ \\
Anti-HBc & and Anti-HBs & $41(12.76)$ \\
\hline
\end{tabular}

An univariate analysis of the variables anti- $\mathrm{HBc}$ and anti-HCV was performed. No significant relation was found when related to anti-HCV. However, there was a significant relationship for anti-HBc related to anti-HCV, area, age, number of hospitalizations and sexual activity. Table 2 summarizes the results for anti-HBc.

Multivariate analysis was conducted using anti-HBc as the dependent variable and as independent variables were considered all those with $P<0.05$ (Table 3 ). In the final model, there was a significant relationship of anti-HBc with the variables "area" and "age". Individuals living more than 1 hour from the city center are 2.198 times more likely to be infected with HBV than individuals who live less than 1 hour from the city center (places located more than 1 hour from the city center are considered rural zone by the local Family Health Program). Finally, individuals with age equal or greater than 60 years had 3.330 times more when compared to individuals with age up to 20 years.

Moreover the multivariate analyses have shown trends of association of anti-HBc with other two variables, "anti$\operatorname{HCV} "(P=0.071)$ and "two or more sexual partners in the last year" $(P=0.068)$.

Other variables were not found to have a significant relationship to the prevalence of $\mathrm{HBV}$, indicating that they could be confounding variables. Multivariate analysis for anti-HCV was not conducted because univariate analysis did not reveal a significant relationship between anti-HCV and any variable.

\section{DISCUSSION}

During the activities of the "Bandeira Cientifica" Project, the patients were attended to medical consultations in 13 different clinics in urban and rural areas of the city. Local health-care agents have selected them. Each clinic covered an area of the city. While seeking treatment at the clinics, the individuals were invited to join this study. Therefore, although it is known that hepatitis B and C are almost always asymptomatic, this study may have included a greater proportion of infected individuals because we only had access to those people who came to the clinics, usually seeking medical assistance (Table 2). However, the volunteers were recruited without the knowledge of either their reason for seeking treatment or their symptoms. Interestingly, the variable "reason of attraction to the place of study", that investigated if the individual was seeking for treatment or not, was not associated to anti-HBc presence $(P=0.328)$. This result may indicate us that the medical condition of the participants probably is not related to the high prevalence of $\mathrm{HBV}$ infection.

An effort was made to include the same number of individuals according to gender and age. Although Buriticupu is not a recent settled area, $62.8 \%$ had lived in the city less than 13 years. The mean family annual income was very low, approximately US\$753.11 per year, usually earned by two people, with an average of five individuals per household. There was a general lack of sanitary conditions: only $0.83 \%$ of participants have garbage collection, $23.46 \%$ have indoor plumbing, and more than $60 \%$ dump their sewage in rivers or open land. Education was also deficient, with $80 \%$ having some education only up to elementary school level. Approximately half of the population has worked in agriculture.

The prevalence of past HBV infection (positive total anti-HBc) found in Buriticupu (40.74\%) is much higher than in other parts of Amazon such as that found in an 
TABLE 2. Univariate analysis for Anti-HBc

\begin{tabular}{|c|c|c|c|c|c|c|c|}
\hline \multirow{2}{*}{$\begin{array}{l}\text { Variables } \\
\text { Anti-VHC }\end{array}$} & & & Ani-HBc- & Anti $\mathrm{HBc}+$ & Beta $( \pm$ SE) & OR (CI95\%) & $\mathbf{P}$ \\
\hline & \multicolumn{2}{|c|}{ Negative (\%) } & $131(58.0)$ & $95(42.0)$ & & 1.00 & \\
\hline \multirow{3}{*}{ Área } & \multicolumn{2}{|c|}{ Positive (\%) } & $11(91.7)$ & $1(8.3)$ & $-2.077 \pm 1.053$ & $0.125(0.016-0.988)$ & 0.049 \\
\hline & \multicolumn{2}{|c|}{ Up to 1 hour of the center $(\%)$} & $97(63.8)$ & $55(36.2)$ & & 1.00 & \\
\hline & \multicolumn{2}{|c|}{ More than 1 hour of the center $(\%)$} & $38(46.9)$ & $43(53.1)$ & $0.691 \pm 0.279$ & $1.996(1.154-3.451)$ & 0.013 \\
\hline \multirow[t]{2}{*}{ Sex } & \multicolumn{2}{|c|}{ Female $(\%)$} & $83(63.8)$ & $47(36.2)$ & & 1.00 & \\
\hline & \multicolumn{2}{|l|}{ Male (\%) } & $61(54.0)$ & $52(46.0)$ & $0.409 \pm 0.263$ & $1.505(0.900-2.519)$ & 0.119 \\
\hline \multirow[t]{4}{*}{ Age } & \multicolumn{2}{|c|}{ Up to 20 years $(\%)$} & $58(79.5)$ & $15(20.5)$ & & 1.00 & \\
\hline & \multicolumn{2}{|c|}{ Between 21 and 40 years (\%) } & $40(54.1)$ & $34(45.9)$ & $1.190 \pm 0.372$ & $3.287(1.586-6.813)$ & 0.001 \\
\hline & \multicolumn{2}{|c|}{ Between 41 and 60 years $(\%)$} & $31(47.0)$ & $35(53.0)$ & $1.474 \pm 0.380$ & $4.366(2.071-9.202)$ & 0.000 \\
\hline & \multicolumn{2}{|c|}{ Greater of that 60 years $(\%)$} & $15(50.0)$ & $15(50.0)$ & $1.352 \pm 0.466$ & $3.867(1.551-9.640)$ & 0.004 \\
\hline \multirow[t]{2}{*}{ State of birth } & \multicolumn{2}{|c|}{ Another one $(\%)$} & $29(60.4)$ & $19(39.6)$ & & 1.00 & \\
\hline & Maranhão ( & & $112(59.3)$ & $77(40.7)$ & $0.048 \pm 0.330$ & $1.049(0.549-2.004)$ & 0.884 \\
\hline Time of residence in & Up to $10 \mathrm{ye}$ & rs $(\%)$ & $79(61.7)$ & $49(38.3)$ & & 1.00 & \\
\hline Maranhão state & Between 11 & and 20 years $(\%)$ & $35(59.3)$ & $24(40.7)$ & $0.100 \pm 0.321$ & $1.106(0.589-2.076)$ & 0.755 \\
\hline & Greater of $t$ & at 20 years $(\%)$ & $27(57.4)$ & $20(42.6)$ & $0.178 \pm 0.347$ & $1.194(0.605-2.356)$ & 0.608 \\
\hline Marital status & Bachelor / v & dower (\%) & $74(70.5)$ & $31(29.5)$ & & 1.00 & \\
\hline & Married (\% & & $68(50.0)$ & $68(50.0)$ & $0.870 \pm 0.274$ & $2.387(1.395-4.086)$ & 0.002 \\
\hline Occupation of the patient & Another on & & $57(79.2)$ & $15(20.8)$ & & 1.00 & \\
\hline & Owner of $\mathrm{H}$ & use $(\%)$ & $27(57.4)$ & $20(42.6)$ & $1.035 \pm 0.414$ & $2.815(1.251-6.334)$ & 0.012 \\
\hline & Farmer (\%) & & $56(46.7)$ & $64(53.3)$ & $1.469 \pm 0.343$ & $4.343(2.217-8.507)$ & 0.000 \\
\hline Years of education of the & $2^{\text {sd }}$ or $3^{\text {rd }} \mathrm{gr}$ & de incomplete (\%) & $16(72.7)$ & $6(27.3)$ & & 1.00 & \\
\hline patient & $1^{\text {st }}$ grade in & mplete $(\%)$ & $106(60.2)$ & $70(39.8)$ & $0.566 \pm 0.503$ & $1.761(0.657-4.719)$ & 0.260 \\
\hline & Illiterate $(\%$ & & $16(50.0)$ & $16(50.0)$ & $0.981 \pm 0.595$ & $2.667(0.831-8.561)$ & 0.099 \\
\hline Contributers to income & Up to two c & ntributors (\%) & 109 (60.9) & $70(39.1)$ & & 1.00 & \\
\hline household & More than $t$ & vo contributors (\%) & $33(54.1)$ & $28(45.9)$ & $0.279 \pm 0.299$ & $1.321(0.735-2.375)$ & 0.352 \\
\hline Individuals in Household & Up to six in & labitants (\%) & $101(59.8)$ & $68(40.2)$ & & 1.00 & \\
\hline & More than s & $\mathrm{x}$ inhabitants (\%) & $42(58.3)$ & $30(41.7)$ & $0.059 \pm 0.286$ & $1.061(0.606-1.858)$ & 0.836 \\
\hline Annual family Income & Until R $\$ 2$ & $00,00(\%)$ & $36(63.2)$ & $21(36.8)$ & & 1.00 & \\
\hline & More than 1 & $\$ 2000,00(\%)$ & $68(55.7)$ & $54(44.3)$ & $0.308 \pm 0.330$ & $1.361(0.714-2.597)$ & 0.349 \\
\hline Habitation & Type & onw $(\%)$ & $124(57.1)$ & $93(42.9)$ & & 1.00 & \\
\hline & & Rented (\%) & $4(80.0)$ & $1(20.0)$ & $-1.099 \pm 1.126$ & $0.333(0.037-3.032)$ & 0.329 \\
\hline & & yielded $(\%)$ & $16(76.2)$ & $5(23.8)$ & $-0.875 \pm 0.530$ & $0.417(0.147-1.178)$ & 0.099 \\
\hline & Floor & Beaten land (\%) & $68(58.6)$ & $48(41.4)$ & & 1.00 & \\
\hline & & Cement $(\%)$ & $70(58.8)$ & $49(41.2)$ & $-0.008 \pm 0.265$ & $0.992(0.590-1.667)$ & 0.975 \\
\hline & & Wood $(\%)$ & $3(75.0)$ & $1(25.0)$ & $-0.750 \pm 1.170$ & $0.472(0.048-4.678)$ & 0.472 \\
\hline & & Another one (\%) & $3(75.0)$ & $1(25)$. & $-0.750 \pm 1.170$ & $0.472(0.048-4.678)$ & 0.472 \\
\hline & Garbage & Burnt $(\%)$ & $89(69.5)$ & $39(30.5)$ & & 1.00 & \\
\hline & & Open sky (\%) & $51(46.4)$ & $59(53.6)$ & $0.971 \pm 0.271$ & $2.640(1.552-4.490)$ & 0.000 \\
\hline & & Collected $(\%)$ & $2(100.0)$ & $0(0.0)$ & -- & 0.000 & --- \\
\hline & & Another one (\%) & $2(100.0)$ & $0(0.0)$ & --- & 0.000 & --- \\
\hline & Sewer & Canalized $(\%)$ & $58(65.9)$ & $30(34.1)$ & & 1.00 & \\
\hline & & River (\%) & $84(54.9)$ & $69(45.1)$ & $0.463 \pm 0.277$ & $1.588(0.922-2.735)$ & 0.095 \\
\hline Hospitalization & Yes $(\%)$ & & $94(57.3)$ & $70(42.7)$ & & 1.00 & \\
\hline & No $(\%)$ & & $49(62.8)$ & $29(37.2)$ & $-0.230 \pm 0.283$ & $0.795(0.457-1.383)$ & 0.416 \\
\hline & Up to $2(\%$ & & $116(63.0)$ & $68(37.0)$ & & 1.00 & \\
\hline & $>2(\%)$ & & $28(47.5)$ & $31(52.5)$ & $0.636 \pm 0.302$ & $1.889(1.045-3.415)$ & 0.035 \\
\hline Tobaccoism & No $(\%)$ & & $103(62.0)$ & $63(38.0)$ & & 1.00 & \\
\hline & Yes or form & r-smoker (\%) & $41(53.9)$ & $35(46.1)$ & $0.333 \pm 0.280$ & $1.396(0.806-2.417)$ & 0.234 \\
\hline Alcoholism & No $(\%)$ & & $123(58.9)$ & $86(41.1)$ & & 1.00 & \\
\hline & Yes $(\%)$ & & $21(63.6)$ & $12(36.4)$ & $-0.202 \pm 0.388$ & $0.817(0.382-1.749)$ & 0.603 \\
\hline Sexual activity & No $(\%)$ & & $63(77.8)$ & $18(22.2)$ & & 1.00 & \\
\hline & Yes $(\%)$ & & $78(49.7)$ & $79(50.3)$ & $1.266 \pm 0.311$ & $3.545(1.926-6.525)$ & 0.000 \\
\hline & Partners & None (\%) & $63(77.8)$ & $18(22.2)$ & & 1.00 & \\
\hline & (Last year) & $1(\%)$ & $68(49.3)$ & $70(50.7)$ & $1.282 \pm 0.317$ & $3.603(1.936-6.705)$ & 0.000 \\
\hline & & 2 or more $(\%)$ & $10(52.6)$ & $9(47.4)$ & $1.147 \pm 0.532$ & $3.150(1.111-8.928)$ & 0.031 \\
\hline Reason of attraction & Another on & (\%) & $32(65.3)$ & $17(34.7)$ & & 1.00 & \\
\hline to the place of study & Medical cor & ultation (\%) & $110(57.6)$ & $81(42.4)$ & $0.326 \pm 0.334$ & $1.386(0.720-2.667)$ & 0.328 \\
\hline
\end{tabular}


TABLE 3. Final multivariate model for Anti-HBc*

\begin{tabular}{|c|c|c|c|c|}
\hline Variables & & Beta $( \pm$ SE) & OR (CI95\%) & $\mathrm{p}$ \\
\hline \multirow[t]{2}{*}{ Anti-HCV } & Negative & & 1.00 & \\
\hline & Positive & $-1.977 \pm 1.095$ & $0.138(0.016-1.183)$ & 0.071 \\
\hline \multirow[t]{2}{*}{ Area } & Up to 1 hour of the center & & 1.00 & \\
\hline & More than 1 hour of the center & $0.787 \pm 0.342$ & $2.198(1.124-4.297)$ & 0.021 \\
\hline \multirow[t]{4}{*}{ Age } & Up to 20 years & & 1.00 & \\
\hline & Between 21 and 40 years & $0.848 \pm 0.582$ & $2.334(0.745-7.310)$ & 0.146 \\
\hline & Between 41 and 60 years & $1.060 \pm 0.584$ & $2.886(0.918-9.073)$ & 0.070 \\
\hline & Greater of that 60 years & $1.203 \pm 0.583$ & $3.330(1.061-10.450)$ & 0.039 \\
\hline \multirow[t]{2}{*}{ Hospitalization } & Up to 2 & & 1.00 & \\
\hline & $>2$ & $0.518 \pm 0.387$ & $1.679(0.786-3.586)$ & 0.180 \\
\hline Sexual activity & None & & 1.00 & \\
\hline Partners & 1 & $0.431 \pm 0.499$ & $1.539(0.578-4.094)$ & 0.388 \\
\hline (Last year) & 2 or more & $1.341 \pm 0.736$ & $3.823(0.904-16.172)$ & 0.068 \\
\hline
\end{tabular}

* Variables included in the initial multivariate model: anti-HCV, area, age, marital status, occupation of the patient, habitation, hospitalization and sexual activity

indigenous population of Rondônia $(35 \%)^{(30)}$. The prevalence is, however, lower than those found in a population of Monte Negro, RO, in the Western region of the Brazilian Amazon $(61.79 \%)^{(16)}$. Buriticupu may therefore be considered an endemic site for $\mathrm{HBV}$ infection, even though the prevalence of current infection or chronic carriers $\left(\mathrm{HBsAg}^{+}\right)$was $2.88 \%$, considered intermediate according to the World Health Organization (WHO) classification. These results have evidenced that $\mathrm{HBV}$ infection is not only endemic in the Western Amazon.

We were not able to establish the definitive reason for this endemic HBV infection. The risk analysis for HBV has shown an increasing risk related with advanced age $(\mathrm{OR}=$ 3.330 , CI $95 \%=1.061-10.450)$ and for individuals living outside of the Buriticupu city center (OR $=2.198$, CI 95\% = 1.124-4.297). The association with advanced age could only reflect that older people have a longer history of exposure to the infection ${ }^{(1)}$. The association between Anti-HBc and long distance residence from the city center may reflect an indirect association between the infection and precarious condition of existence, offering a plausible hypothesis for the high HBV prevalence in Buriticupu. However some factors that have been related to hepatitis $\mathrm{B}$ and $\mathrm{C}$ infection, such as intravenous drugs, delta hepatitis, were not investigated, which may be considered a limitation for the present study.

We found $12.76 \%$ of participants to be potentially immunized against $\mathrm{HBV}$ through vaccination (anti- $\mathrm{HBc}^{-}, \mathrm{HBsAg}^{-}$and anti- $\mathrm{HBs}^{+}$), which could be contrasted with a reported rate of vaccine coverage of $35 \%$ in all ages in the state of Maranhão, according to the Brazilian National Immunization Program $(\mathrm{NIP})^{(4)}$. This may be because some individuals could have immunization through vaccines and/or contact, not being a separated group in the study. An interesting point is that vaccination coverage was much higher among infants $(>70 \%$ of coverage among infants 0 to 10 years old), which may suggest an improvement of NIP in the last years.

The prevalence of $5.76 \%$ of hepatitis C (anti-HCV) is higher than the worldwide estimate of $3 \%$, according to the $\mathrm{WHO}^{(21)}$. As it occurs with the HBV infection, there is a great variation in the prevalence rates in different regions, being around $1.8 \%$ in the $\mathrm{USA}^{(14)}$, to $20 \%$ in the district of Yamagata in $\operatorname{Japan}^{(37)}$, a region that was considered endemic for hepatitis C from 1967 to 1972, but with no established transmission route. Although there is no official data on the prevalence of $\mathrm{HCV}$ in Brazil, the seroprevalence found in the Amazon region ranges from $0.38 \%$ in the Western region ${ }^{(16)}$ to $2.4 \%$ in a group in the southern region ${ }^{(30)}$, the latter related to intravenous drug abuse. A study conducted in rural communities of Northeastern Brazil, with a high prevalence of Schistosomiasis mansoni, has shown a very low prevalence of hepatitis $\mathrm{C}$ virus infection ${ }^{(32)}$.

Although risk analysis evidences no relation to $\mathrm{HCV}$, its distribution was similar to HBsAg according to age, except to infants, which was comparatively much higher. It may reflect the result of infant immunization against HBV that may diminish the chance of chronic hepatitis B in the future $\left(\mathrm{HBsAg}^{+}\right)^{(20)}$.

Such type of investigation is important because there are few studies of prevalence of HBV and HCV infection in Brazil. The presented results may be used in order to better organize ways to prevent diseases with high potential to cause chronic hepatitis, cirrhosis and liver tumor ${ }^{(10)}$. In conclusion, Buriticupu may be considered an endemic site for HBV infection, and the prevalence of HCV is higher than the worldwide estimate. Thus, based on the results of the present investigation, public health education programs on HBV and HCV infection, hepatitis B immunization programs, and raising socioeconomic standards should be initiated in order to improve the actual reality. More studies are needed to confirm the current status of HBV and HVC infections in this region as well as to clarify the main routes of transmission in the Amazon region.

\section{ACKNOWLEDGEMENTS}

Supported by: Conselho Nacional de Desenvolvimento Científico e Tecnológico/"National Council of Technological and Scientific Development" (CNPq); Fundação de Amparo à Pesquisa do Estado de São Paulo/"The State of São Paulo Research Foundation" (FAPESP). 
El Khouri M, Cordeiro Q, Luz DABP, Duarte LS, Gama MEA, Corbett CEP. Endemia de infecção de hepatites B e C em uma região do leste da Amazônia brasileira. Arq Gastroenterol. 2010;47(1):35-41.

RESUMO - Contexto - Infecção por hepatites B e C tem sido causa importante de morbimortalidade em todo o mundo. Entretanto, há poucas investigações sobre a prevalência e possíveis fatores de risco relacionados a tais doenças no Brasil, especialmente na região amazônica, onde há algumas regiões endêmicas para tais quadros clínicos. Objetivos - Detectar a prevalência de hepatites B e C na cidade de Buriticupu, MA, localizada na região leste da Amazônia brasileira, e tentar investigar seus fatores de risco nessa área. Métodos - Duzentos e quarenta e três indivíduos (46,5\% masculinos e 53,5\% femininos) foram investigados. Resultados - A prevalência de hepatite C foi de 5,71\% (anti-HCV) e a de hepatite B foi de 40,74\% (anti-HBc). A prevalência de indivíduos com infecção atual ou com infecção crônica foi de 2,80\% (HBsAg). Houve relação estatisticamente significante entre anti-HBc e a distância da residência dos indivíduos do centro da cidade, o que pode refletir uma associação indireta entre tal quadro infeccioso e condições precárias de existência. Indivíduos com idade igual ou maior a 60 anos também apresentaram maior chance de apresentarem sorologia para anti-HBc, o que pode refletir apenas que pessoas mais velhas apresentam história maior de exposição à infecção. A prevalência de hepatite C é maior do que a mundial estimada. Conclusão - Buriticupu pode ser considerada endêmica para hepatites B e C. Hepatite B pode estar relacionada com precárias condições de vida e idade avançada. Hepatite $\mathrm{C}$ não foi associada com as variáveis investigadas na presente investigação.

DESCRITORES - Hepatite B, epidemiologia. Hepatite C, epidemiologia. Estudos soroepidemiológicos. Antígenos do núcleo do vírus da hepatite B. Antígenos de superfície da hepatite B.

\section{REFERENCES}

1. Behal R, Jain R, Behal KK, Bhagoliwal A, Aggarwal N, Dhole TN. Seroprevalence and risk factors for hepatitis $\mathrm{B}$ virus infection among general population in Northern India. Arq Gastroenterol. 2008;45:137-40.

2. Bonkovsky HL, Metha S. Hepatitis C: a review and update. J Am Acad Dermatol. 2001:44:159-82.

3. Brasil. Ministério da Saúde. Centro Nacional de Epidemiologia - Indicadores e dados básicos. Brasília; 1998.

4. Brasil. Ministério da Saúde. Programa Nacional de Imunizações. Indicadores e dados básicos. Brasília; 2003.

5. Brasil. Ministério da Saúde. Sistema de Informação de Agravos de Notificação. Indicadores e Dados Básicos. Brasília; 2003.

6. Brasil LM, Braga WSM, Castejón MJ, Fonseca JCF. Prevalence of hepatitis B virus (HBV) infection in children, Codajas, Amazon Basin, Brazil: a pre-study vaccination. Acta Hepatol. 1991;1:26.

7. Chen CJ, Wang LY, Yu MW. Epidemiology of hepatitis B virus infection in the Asia-Pacific region. J Gastroenterol Hepatol. 2000;15:3-6.

8. Conte VP. Multicenter study on the prevalence of hepatitis $\mathrm{C}$ virus infection in blood donors in the city of Curitiba, Brazil. Arq Gastroenterol. 1999;36: 117-21.

9. Conte VP. Chronic viral hepatitis C. Part 1. General considerations. Arq Gastroenterol. 2000;37:187-94.

10. Coral G, de Mattos AA, de Mattos AZ, dos Santos DE. Steatosis and nonalcoholic steatohepatitis in patients with chronic hepatitis due to hepatitis $\mathrm{C}$ virus infection. Arq Gastroenterol. 2006;43:265-8.

11. Crawford J. The liver and the biliary tract. In: Cotran RS, Kumar V, Collins T, editors. Pathologic basis of disease. Philadelphia: Saunders; 1999. p.857-62.

12. De Paula VS, Arruda ME, Vitral CL. Seroprevalence of viral hepatitis in riverine communities from the Western Region of the Brazilian Amazon Basin. Mem Inst Oswaldo Cruz. 2001;96:1123-8.

13. Dos Santos VA, Azevedo RS, Camargo ME, Venâncio AFA. Effect of new evaluation of cutoff values for enzyme-linked immunosorbent assay in Brazilian patients. AJCP. 1999;112:418-24.

14. El Khouri M, Dos Santos, VA. Hepatitis B: epidemiological, immunological and serological considerations emphasizing mutation. Rev Hosp Clin Fac Med S Paulo. 2004;59:216-24.

15. El Khouri M, Duarte LS, Gyuricza J, Corbett CEP. Partnership between universities and the local healthcare system to benefit the town of Buriticupu, a poor community in the state of Maranhao, Brazil. Clinics. 2005;60:82-4.

16. El Khouri M, Duarte LS, Ribeiro RB, da Silva LF, Camargo LM, dos Santos VA, Burattini MN, Corbett CEP. Seroprevalence of hepatitis B virus and hepatitis $\mathrm{C}$ virus in Monte Negro in the Brazilian Western Amazon region. Clinics. 2005;60:29-36.

17. Feng X. Hepatitis C infection: a review. Lippincotts Prim Care Pract. 1999;3: 345-53.
18. Ferrari JO, Ferreira MU, Tanaka A, Mizokami M. The seroprevalence of hepatitis $\mathrm{B}$ and $\mathrm{C}$ in an Amerindian population in the Southwestern Brazilian Amazon. Rev Soc Bras Med Trop. 1999;32:299-302.

19. Galperim B, Cheinquer H, Stein A, Fonseca A, Lunge V, Ikuta N. Prevalence of hepatitis $\mathrm{C}$ virus in alcoholic patients: role of parenteral risk factors. Arq Gastroenterol. 2006;43:81-4.

20. Gambarin-Gelwan M. Hepatitis B in pregnancy. Clin Liver Dis. 2007;11:945-63.

21. Global surveillance and control of Hepatitis C. Report of WHO Consultation organized in collaboration with the Viral Hepatitis Prevention Board, Antwerp, Belgium. J Viral Hepat. 1999;6:35-47.

22. Hagan H, Des Jarlais DC. HIV and HCV infection among injecting drug users Mt Sinai J Med. 2000;67:423-8.

23. Hyams KC. Mosquito transmission of hepatitis B. Trop Geogr Med. 1989;41: $185-9$.

24. Kao JH, Chen DS. Global control of hepatitis B virus infection. Lancet Infect Dis. 2002;2:395-403.

25. Kim YS, Lee HS, Ahn YO. Factors associated with positive predictability of the anti-HCV ELISA method with confirmatory RT-PCR. J Korean Med Sci. 1999;14:629-34.

26. Maddrey WC. Hepatitis B-an important public health issue. Clin Lab. 2001;47:51-5.

27. Parolin MB, Russo AA, de Almeida PT, Baldanzi GR, Lopes RW. Multicenter study on the prevalence of hepatitis $\mathrm{C}$ virus infection in blood donors in the city of Curitiba, Brazil. Arq Gastroenterol. 1999;36:117-21.

28. Roingeard P, Diouf A, Mboup S, Diadhiou F, Essex M. Perinatal transmission of hepatitis B virus in Senegal. Proceedings of the $8^{\text {th }}$ International Symposium on Viral Hepatitis and Liver Disease; 1993. Tokyo, Japan; 1993.

29. Silva L, Paraná R, Mota E, Cotrim HP, Boënnec-McCurtey ML, Vitvitinsky L, Pádua A, Trepo C, Lyra L. Prevalence of hepatitis C virus in urban and rura populations of northeast Brazil-pilot study. Arq Gastroenterol. 1995;32:168-71.

30. Souto FJ, Fontes CJ, Martelli CM, Turchi MD, Martins RM, Andrade AL. Hepatitis $\mathrm{C}$ virus prevalence among an immigrant community to the Southern Amazon, Brazil. Mem Inst Oswaldo Cruz. 1999;94:719-23.

31. Tandon BN, Acharya SK, Tandon A. Epidemiology of hepatitis B virus infection in India. Gut. 1996;38:56-9.

32. Tavares-Neto J, Prata A, Parana R, Valente VB, Vitvitsky L, Figueiredo JF. Very low prevalence of hepatitis $\mathrm{C}$ virus infection among Northeastern Brazil with a high prevalence of schitossomiasis mansoni. Rev Soc Bras Med Trop. 2005;28:290-3.

33. Touzet S, Kraemer L, Colin C, Pradat P, Lanoir D, Bailly F, Coppola RC, Sauleda S, Thursz MR, Tillmann H, Alberti A, Braconier JH, Esteban JI, Hadziyannis SJ, Manns MP, Saracco G, Thomas HC, Trépo C. Epidemiology of hepatitis $\mathrm{C}$ virus infection in seven European Union countries: a critical analysis of the literature. HENCORE Group (Hepatitis C European Network for Co-operative Research). Eur J Gastroenterol Hepatol. 2000;12:667-78.

34. Tovo CV, Dos Santos DE, de Mattos AZ, de Almeida PR, de Mattos AA, Santos $\mathrm{BR}$. Ambulatorial prevalence of hepatitis $\mathrm{B}$ and $\mathrm{C}$ markers in patients with 
human immunodeficiency virus infection in a general hospital. Arq Gastroenterol. 2006;43:73-6.

35. Williams I. Epidemiology of hepatitis C in United States. Am J Med. 1999;107(6B): $2 \mathrm{~s}-9 \mathrm{~s}$.

36. World Health Organization. Towards the elimination of hepatitis B: a guide to the implementation of national immunization programs in the developing world. Washington: Program for Appropriate Technology in Health - PATH; 1994.

37. Yoshii E, Shinzawa H, Saito T, Shao L, Kuboki M, Saito K, Togashi H, Takahashi
T, Mizokami M. Molecular epidemiology of hepatitis $\mathrm{C}$ virus infection in an area endemic for community-acquired acute hepatitis C. Tohoku J Exp Med 1999;188:311-6.

38. Zheng Y, Liu D, Feng D, Tang H, Li Y, You X. An animal study on transmission of hepatitis B virus through mosquitoes. Chin Med J. 1995;108:895-7.

Received 17/3/2009. Accepted 21/7/2009. 